\title{
Russian Suffragists and International Suffragist Organisations: Solidarity, Discipleship, Victory
}

\author{
Irina Iukina ${ }^{1 *}$
}

Published: September 8, 2020

\begin{abstract}
This article serves to throw light on how suffragism developed in Russia at the beginning of the 20th Century. In 1905, the first Russian electoral law was enacted, granting men, but not women, the right to vote. Russian suffragists began forming organisations with the specific goal of achieving women's voting. This paper intends to describe the strategies and tactics Russian suffragists employed in order to achieve female suffrage. This will include analysing the successful practices of their 'Western sisters', as Russian suffragists labelled their foreign colleagues, and adapting their practices to the circumstances prevailing in Russia, as well as promoting suffragism in the Russian press as well as maintaining contacts with international suffragist organisations. The result was the granting of full voting rights to Russian women in 1917. The history of Russian suffragism is barely known in the overall history of suffragism worldwide. This was the result of Soviet propaganda which instilled the idea that women's suffrage in Russia was solely due to the Soviet authority. In modern research, this trend has been overcome, though we still do not know much about Russia's key contributions to suffragism. The article also serves as a tribute to a majority of unknown Russian suffragists for their immense efforts achieved the right voting for women in Russia.
\end{abstract}

Keywords: Russian suffragists, women's suffrage, international suffragist organisations, sisterhood, solidarity

\section{INTRODUCTION}

The history of interaction Russian suffragism with international women's organisations, as well as national suffragism movements of Europe and America is insufficiently studied. The general picture of Russian participation in the international suffrage movement at the beginning of the twentieth century appears more like a broken mosaic, some fragments preserved, others completely absent. The victory of Russian suffragists in obtaining women's universal suffrage has long been unknown in Russia and abroad. Soviet propaganda actively promoted the idea that the Soviet government granted women 'everything', including voting rights. Due to strict ideological control, Soviet historians could not study non-revolutionary social movements, the development of civil society and democratic institutions in tsarist Russia, electoral policy and the struggle for suffrage. Soviet propaganda myths about the absence of feminism and suffragism in pre-Soviet Russia were dispelled by foreign scholars who challenged and rendered the Russian movement visible. Prominent scholars mentioned are Richard Stites, Linda H. Edmondson, and Rochelle G. Ruthchild (Stites, 1978, 1991; Edmondson, 1984; Ruthchild, 2010). Their works refer to contacts by Russian feminists with international organisations; however, this is not the primary focus of their scholarship as studied by Laurie R. Cohen (2012) who explores the interaction of Russian feminists with the Women's International League for Peace and Freedom.

In Russian historiography, Russian feminism and suffragism began to be studied in the mid 1980s, when Soviet ideological pressure disappeared under perestroik $a^{1}$. The first historian to study the interaction between Russian women and international women's organisations was Natalia Gafizova, whose work is directly devoted to the interaction of Russian women with the International Council of Women (1888), the International Women Suffrage

1 'Perestroika' ('rebuilding') was a policy President Mikhail Gorbachev as last leader of the Soviet Union, tried to implement from 1985 to the collapse of the Soviet Union in 1991. It began establishing a market economy by encouraging limited private ownership, freedoms of assembly, speech, and religion, the right to strike, and multicandidate elections, and undermined the Soviet Union's authoritarian structures. It ended with the collapse of the Soviet Union. 
Alliance (1902), the International Women's Socialist Secretariat (1907), and the Congress on the White Slave Traffic (1899) (Gafizova, 2003; 2017). Olga Shnyrova is another researcher who studied the interaction between Russian - English and Russian- Finnish suffragists (Shnyrova, 2009; 2016).

In light of these efforts, many fragments of the larger picture have been restored through various sources. The participation of Russian women in conferences of international organisations is especially well represented. At this juncture we know the names of those participants, the topics of their reports, and to some extent the summary of those reports, which allows us to reconstruct the problems that Russian feminists discussed with their 'Western sisters'2. Unfortunately, lack of information on the existence of personal documents makes it impossible to find out how discussions developed, which opinions expressed and by whom, how personal relations progressed and how common tactics were adopted. This exploratory work is yet to be realised and needs to be probed in personal documents such as letters, memoirs, and suffragists' interviews in the national archives of different countries to create a more complete picture of the past.

Still, we can hear the voices of the Russian participants in the international suffragist movement in publications - articles, brochures, and translations in which they shared their impressions of international congresses and analysed what they had heard and seen. These texts are key to understanding how Russian feminists evaluated the international women's movement, why they strove to become its members, and what they considered useful in the experience of other countries. They represented themselves as researchers into the activities of international movements', on the one hand, and as followers who studied and then encouraged their compatriots to learn from the experiences of others. That was happening during a short period from 1905, when Russia transitioned to a constitutional monarchy and the first electoral law (for men) was adopted in December 11th, 1905, to July 20th, 1917, when Russian women won the fight for universal suffrage.

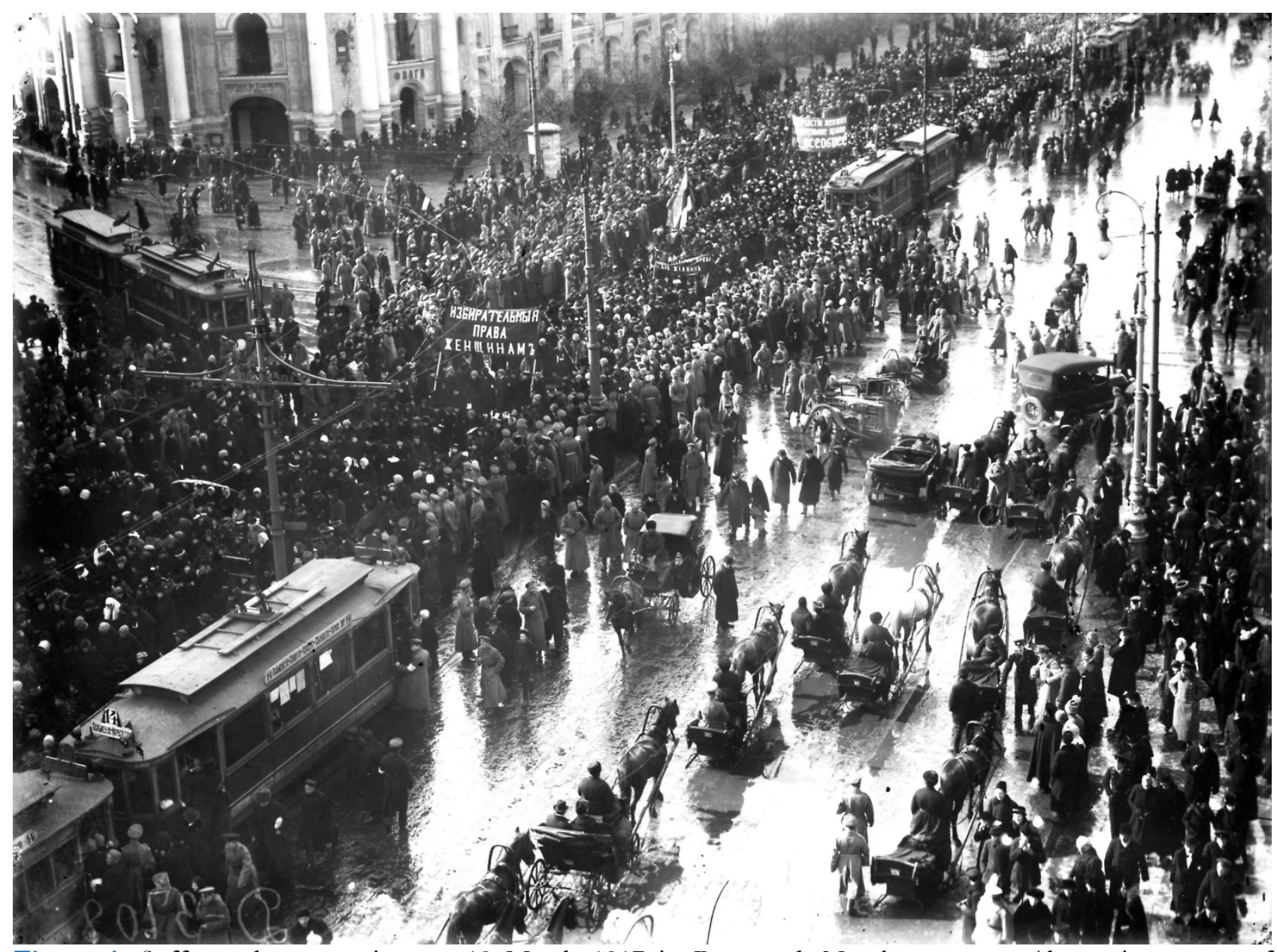

Figure 1. Suffrage demonstration on 19 March 1917 in Petrograd, Nevsky prospect (the main avenue of Petrograd). The banner reads: 'Voting rights for women'. Source: The Central State Archive of Film, Photo and Phonograph Documents, St. Petersburg. D. 3708.

\footnotetext{
2 'Western sisters' is the commonly used term for members of the women's movement in Western Europe and America.
} Russian feminists used it in their articles and speeches. 


\section{PREHISTORY OF THE RUSSIAN SUFFRAGE MOVEMENT}

As Russia turned to modernisation later than most Western European countries and North America, the possibility of forming legal women's organisations, and not just private women's initiatives, became possible only in the 1860s, thanks to the Great Reforms of Alexander II. The country underwent a liberal transformation. The basis of the reforms was the abolition of serfdom in 1861. This was followed by judicial, military, and university reforms, the establishment of local self-government, the weakening of censorship, freedom of speech, and the right to establish non-governmental organisations and societies, etc. On a wave of social upsurge, women's private initiatives began to turn into legally recognised women's organisations and the women's movement was formed.

Women's organisations appeared in the major cities of the Empire. This was facilitated by a change in legislation: it became much easier to get permission from the authorities to start an organisation. In St. Petersburg and Moscow, a whole network of women's organisations that helped women solve various everyday problems in a rapidly changing society came into being. The most urgent issues of education, employment and collective housing were resolved through mutual support and charitable activities, which resulted in such social innovations as access for women to higher education, college dorms, and special educational funds.

Women's suffrage was not on the agenda of the Russian women's movement at the beginning of its existence. At that time, neither the institution of parliamentarism nor voting rights existed in Russia. No one had voting rights: neither men nor women. The absence of any electoral rights was a distinctive feature of Russia. That must have been the reason why many men were very loyal to the women's movement and in Russia social thought and journalism lacked a stark misogyny. It is this situation of equality in the absence of rights that explains the solidarity of men and their active participation in solving 'the woman question'. ${ }^{3}$ Such well-known publicists as Dmitry Pisarev, Mikhail Mikhailov, Nikolai Mikhailovsky and other opinion-shapers of the 1860s promoted 'the woman question' in popular magazines. Nikolai Chernyshevsky wrote a novel on the topic with the expressive title What is to be done? (1863). Prominent scientists such as Dmitry Mendeleev, Ivan Sechenov, Alexander Borodin and others agreed to teach at the Higher Women's Courses in St. Petersburg free of charge during the courses' first year. Later they received a minimal payment. Such examples of men's solidarity were numerous. Moreover, women's demands for support in education and employment became almost a cultural norm amongst men of the educated classes with democratic beliefs.

As soon as the revolution of 1905 decisively put on the political agenda the demand for universal suffrage, the situation changed. Women's organisations that had put forward their demand for women's suffrage were to be neither heard nor supported by yesterday's friends - liberal parties and politicians. 'Women's rights' among the liberal male intelligentsia were interpreted as the right to higher education, professional employment, and the expansion of women's rights in the family, i.e. they were considered within the framework of the 'woman question'. However, it was not enough for the participants of the women's movement in the newly changed circumstances. They wanted political rights. The feminists joined parties, political organisations such as the Union of Unions, the Red Cross, and the Unemployment Commission in order to promote their ideas, and they tried to include the requirement of women's suffrage in their agenda. At best, they encountered some indifference, and often resistance. It became clear that women's suffrage was not on the agenda of either liberals or social democrats, not to mention the conservatives. The attempt to integrate the requirement of women's suffrage into the national political agenda failed in 1905. It became necessary for feminists to create their own suffragist organisations and fight for their rights themselves.

Under the electoral law of 11 December 1905, Russian men won voting rights, whereas women did not. The first Russian Parliament - the State Duma - opened in the spring of 1906 without female representation. The feminist magazine Zhenskii vestnik ('Women's Herald') commented:

The end of last year not only destroyed women's hopes for equality but also put before them a highly surprising question: can they be considered as part of the population or not? (Zhenshchiny ne priznayutsya v Rossii naseleniem, 1906: n. p.)

Therefore, we can talk about the formation of Russian suffragism starting in 1905, when the task of obtaining electoral rights was set as a practical and strategic goal of the women's movement. Women's suffrage entered the sphere of interests of Russian feminists at the end of the 19th century, but they looked upon this issue as purely theoretical in Russia, such as women's struggles for emancipation abroad, foremost in Britain.

It is impossible not to mention the influence of English political thought, foremost the works of J. S. Mill. His The Subjection of Women was so popular that it saw many editions since 1869 and it was called the Women's Bible.

\footnotetext{
3 The 'woman question' denoted a set of social problems faced by women in a modernising society. As a solution to the women's issue, it was proposed to provide women access to professional education and employment, and to expand their rights in the family.
} 
1905 gave an impetus to the theorisation of women's suffrage in relation to the Russian reality. Russian feminists who were looking for arguments in favour of women's suffrage, formed the concept of female citizenship, and created the image of the female citizen. That is why in 1907 N. Mirovich ${ }^{4}$ translated and published Mill's speech, originally delivered on May 20 $0^{\text {th }}, 1867$ in the House of Commons, arguing that British women should be given the vote (Ruthchild, 2001c). She wrote in the introduction: "Mill's noble speech in defense of a woman (...) is modern in Russia just now" (Mill, 1907 n.p). The experience of the struggle for suffrage in other countries became relevant for the Russians, because Russia stood in the same position as most other countries - having inequality between women and men in voting rights.

\section{THE FIRST SUFFRAGIST ORGANISATIONS IN RUSSIA}

The first suffragist organisations whose main goal was to achieve equal electoral rights for women appeared in 1905. They were the Women's Equal Rights Union (February 1905), the Women's Progressive Party (December 1905), the Club of Women's Progressive Party (1906), the Women's Political Club (1906), and the League for Women's Equal Rights (1907). ${ }^{5}$ The so-called 'old' women's organisations, which dealt with women's education and employment, also supported those demands. They made changes to their charters, opening women's suffrage sections and so on. However, the central players were the Women's Equal Rights Union (henceforth WERU), the Women's Progressive Party (henceforth WPP), and the League for Women's Equal Rights (henceforth LWER), which continued the actions of the WERU. The WERU and the WPP joined the International Women Suffrage Alliance (henceforth IWSA).

The women's movement and feminism were a middle-class women activity. The Russian middle class only began to evolve in Russia in the course of the Great Reforms of the 1860s when society had turned from being feudal to being relatively modern. In that complex and long process, the middle class was made up of people from various social groups. The features which set them apart from other classes were their professional education, employment in intellectual professions, and living on their earnings. 'Middle-class women' were, in effect, the women of the intelligentsia who had fought hard to defend their right to obtain a professional education and professional work, and who could just about survive on their modest earnings; by origin, most of them were noblewomen.

These educated noblewomen created the structures of women's education and employment. They solved the problems typical for the initial phase of many women's movements all over the world. That is access to education from classical gymnasia to higher education including university ${ }^{6}$, employment, and the extension of women's civil rights. There were projects dealing with job creation. However, sewing workshops that women activists in the 1860s had set up for lower class women did not last long; they were closed down by the authorities. Nevertheless, Artel, ${ }^{7}$ a cooperative of women-translators, and the women's printing house provided educated women with jobs for many years to come (Muravyeva, 2006b; Novikova, 2006b).

An obstacle to the further development of the women's movement was the rigid authoritarianism of the authorities. After the 'thaw' of the 1860s, the government strengthened its control over the activities of civil organisations. In the late 1870s it was already difficult to get a permit from the Ministry of the Interior to open a new organisation; in the 1890s it became almost impossible. Created in 1895, the Russian Women's Mutual Philanthropic Society (henceforth RWMPS) made its appearance only owing to the organisation's founders' high connections at Court. They had to take the cumbersome name Russian Women's Mutual Philanthropic Society, instead of the Women's Club they had initially come up with. The government could still recognise philanthropy as a sphere of women's activity, but it did not approve of any women's clubs modelled on men's, as previously planned. All meetings were attended by a policeman, who made sure that the speakers did not deviate from the stated topic. He had the right to close the meeting and did so in fact, if he came to the conclusion that the 'ladies' were discussing politics. The forms of activities of women's organisations also had to be approved by the authorities. For example, in 1901 the governor of St. Petersburg banned the activity of the RWMPS' reporting section for the 'exchange of thoughts' (like a discussion club) because its members held debates on social problems. Starting in 1909 the Society applied for permission to change its charter and to expand its activities, but in vain.

\footnotetext{
4 'N. Mirovich' is the pseudonym of Zinaida Ivanova (1865 - 1913) - writer, critic, translator, historian, one of the founders of the Women's Equal Rights Union.

5 The League for Women's Equal Rights $(1907$ - 1917) substituted the Women's Equal Rights Union after it ceased to exist in 1907.

${ }^{6}$ One of the first women's classical gymnasiums which prepared women for University was opened in 1870 by Duchess Alexandra Obolenskaya in St. Petersburg. To do this, she had to finish a pedagogical course and get a teacher's diploma. This story caused a shock in the aristocratic circles of St. Petersburg.

7 The Artel of women-translators was registered as a private enterprise of Nadezhda Stasova (1822-1895) and Maria Trubnikova (1835-1897), the founders of the women's movement.
}

$4 / 16$

(C) 2020 by Author/s 
The laws on women's civil rights changed slowly and only under pressure from women's organisations. They lobbied for almost twenty years for a change in the law to allow married women to get a passport, to attend an educational course or to be employed, or to separate without their husband's consent ${ }^{8}$. Obtaining the right to vote and further participation in political life seemed to the activists the only way to solve all their problems. Most Russian feminists believed that when women finally entered the Parliament, they would draft laws and not only solve the problems, but also contribute to the development and humanisation of society as a whole. These dreams were voiced in speeches, in tracts, and illustrations in women's magazines.

\section{RELATIONS WITH INTERNATIONAL WOMEN'S ORGANISATIONS}

The Russian ravnopravki $i^{9}$ - mostly educated middle-class women but also from the upper classes - considered that they lived in an authoritarian country with a tradition of despotism that had just embarked on democratic change. They avidly followed developments in parliamentary monarchies around the world. Republican regimes in Europe, such as France and Switzerland, did not arouse their interest; in the ravnopravkis opinion, the struggle for women's rights was 'insufficient' there and they often voiced criticism of the movements in these countries (Mirovich, 1901, 1907b; 1909b; Student V.V. Lush, 1907).

Their eyes were turned foremost to Britain, a country with democratic foundations in their opinion. They watched how the British suffragists worked with democratic institutions such as parliament, the parties, the trade unions, and the independent press. All this was new to Russia, which was undergoing reform. Russian activists judged the activity of British suffragists highly and believed that they should be emulated, because Britain was just one step away from women's voting rights:

In Russia, the principle of freedom and equality will only be realised in the more or less distant future, while in England women will very soon reach equality with men. It will happen both due to historical conditions (...) and due to the different nature of nations (Mirovich, 1909a).

There are many writings about the British women's suffrage movement in the legacy of the Russian feminists ${ }^{10}$. Mirovich described English suffragists as the 'Anglo-Saxon intelligentsia'(intellectuals) with a 'high degree of culture' and noted their 'respect for individual views' (Mirovich, 1901: 256). She considered 'deep faith in the [feminist] idea' and 'commitment to the goal [of suffrage]' as distinguishing features of the British women's movement. "A happy country is one where such civic virtues flourish!" she exclaimed (Mirovich, 1901: 253). Another participant of the movement, Lidia Maslova, ${ }^{11}$ wrote that English women were 'my favourites among foreigners' (Maslova, 1907: 12).

Another country that the Russian feminists closely followed was the United States. Perhaps the reason for this lay in the energy of American women in creating international women's organisations. Russian suffragists saw in English and American women pioneers of suffragism, who managed to introduce the issue of women's voting rights on the political agenda of their countries, i.e. what they still had to do. Lydia Davydova ${ }^{12}$ called them 'free female citizens of England and America' (Davydova, 1899: 42). This is why the Russian suffragists considered them as more experienced comrades-in-arms from whom they had something to learn. Soiuz zhenshchin ('Women's Union') addressed to readers in its first issue:

There is no doubt that it [women's question's] positive for women settlement will be greatly accelerated if we inform society about where and to what extent it has already been realized in Europe, as well as about its results (Peterburg, Iyun', 1907: 2).

Russian women joined the emerging international women's movement in 1873, when they took part in the creation of the International Women's League in New York. According to Linda Edmondson, these women lived abroad and wanted to create an affiliated branch of the League in Russia (Edmondson, 1984: 105). The project failed, but as individuals Russian women could take part in the activities of international structures without any problems. As an example, Ekaterina Gardner of Russia became the secretary of the International Women's League (Ruthchild, 2010: 20). At the same time, it was impossible to register a women's organisation officially as an

\footnotetext{
${ }^{8}$ The law entitled 'On certain changes and additions to existing laws on personal and property rights of women and on the relations of spouses between themselves and children' was adopted by the IV State Duma in February 1914.

${ }^{9}$ Ravnopravki is a synonym for suffragists, translatable as 'equal-righters'.

${ }^{10}$ Russian authors would sometimes use 'English' when they meant British as a whole.

${ }^{11}$ Lydia Maslova was a journalist, member of the Union of Foreign Press in London.

${ }^{12}$ Lydia Davydova (1869-1900) was a journalist, translator, chief of the foreign department of Mir Bozbii ('World of God'), and an active participant of the women's movement.
} 
affiliated member of an international organisation in Russia. These Russian women joined in suffragist activity when it was still not possible to do so at home, and they tried to extend such practices to Russia. The next step was the organisation of an exhibition on women's education and female writing labour in Russia at the International Women's Congress (IWC), held at the Chicago World Fair in 1893.

The decision to join international women's organisations and participate in international actions is explained by Rochelle Ruthchild, who believed that Russian feminists, being under strong pressure and control in Russia, highly appreciated the possibility of contact with the feminist movements of other countries (Ruthchild, 2010: 20). Linda Edmondson argues that most of the Russian feminists, with few exceptions, were 'westernizers', a preference that, in her view, explains their participation in international women's events (Edmondson, 1984: 107). I would refrain from such a definition because it is highly politicised. This is a term often 'rewarded' to those who advocated the democratic path of Russia's development. Russian feminists believed that international congresses 'could bring together women from different countries, help them unite and act together for the sake of the common goal' (Mirovich, 1901: 253).

At the same time, I agree with Edmondson's statement that Russian feminists saw internationalism as the essence of the women's movement (Edmondson, 1984: 108). To develop this point of view, I add that they saw the universal nature of women's issues, regardless of political systems and national characteristics. They had already achieved a lot in their activity and wanted to publicise their movement, as well as learning about other people's experience and, if possible, to use it. Mirovich evaluated the result of the meetings at congresses thusly:

Acquaintance with representatives of other nations (...) influenced the mental horizon. New views, concepts, a new system of life were opening for us (...) meeting with representatives of other nations encouraged us to be more modest about ourselves and value others more because each country gave something that others did not have. Each brought their own experience, the brainchild of their work, to the common treasury of knowledge (Mirovich, 1907b: 9).

This desire to join in international actions speaks about a pragmatic search for allies. They sought them inside the country, and when international women's organisations made their appearance, they began to do so abroad. It was the most obvious step: to discuss their problems with like-minded women, who had already taken the path of political struggle for women's right to the vote, and to receive solidarity and support in return. Through their very existence, international women's organisations demonstrated the international character and universality of women's problems, and this served as support for women's organisations around the world, including in Russia:

Everywhere they [women's movements] arise under the influence, on the one hand, of the awakening self-consciousness in the individual personality, and on the other, under the pressure of economic conditions. Everywhere this awakening of the female personality was rebuffed by the men who had seized power (...) Getting acquainted with the movement more closely, we see that under this external diversity similar homogeneous features are hidden (Mirovich, 1907b: 9).

Russian organisations needed an international support perhaps even more, because the isolationist policies pursued by its government fostered a sense of provincialism, of isolation from contemporary global trends. Participation in international actions added significance to their movement, both in their own eyes and in the eyes of their opponents. Besides, it was a powerful argument in discussions. An example is to be found in the words of Anna Kalmanovich ${ }^{13}$ at a public lecture in the provincial town of Saratov (Ruthchild, 2006a). Inspired by the meeting of International Women's Congress in Berlin (1904), she declared her opponents that:

You tell us we do not recognize the women's movement. Recognize it or not, but it's a fait accompli and sooner or later you will have to reckon with it also [with us]. The women's movement was not invented by the Ladies' Committee of the Saratov Society for the Poor - on the contrary, it is a new cultural movement unprecedented in the history of mankind (Kal'manovich, 1905: III-IV).

In 1899, a delegation of the already mentioned RWMPS took part in the IWC London Congress, where Russian feminists made presentations, and one of the founders of the Russian women's movement, Anna Filosofova ${ }^{14}$ was elected honorary vice president in absentia (Davydova, 1899; Mirovich, 1901; Tyrkova, 1915; Muravyeva, 2006a). With this, she was given the task to create the Russian Council of Women so that Russia could be officially admitted to the ICW. The Russian government did not want Russian women to join the international women's movement, and it prevented the creation of a nationwide women's organisation in the country. On this topic, Filosofova and

\footnotetext{
${ }^{13}$ Anna Kalmanovich (?-1920) was a translator, publicist, correspondent of Zhenskii vestnik, Soiuz zhenshchin, Jus suffragii, and active member of the Russian feminist movement.

14 Anna Filosofova (1837-1912) was one of the founders of Russian women's movement.
}

$6 / 16$

(C) 2020 by Author/s 
Lady Aberdeen were in constant correspondence ${ }^{15}$. Despite all efforts by feminists from 1899 to 1917, the Russian Council of Women was created only in March 1917 and officially joined the ICW only after the fall of tsarist power. But the Russian Council had little time for any activity, as in October 1917 the Bolsheviks took power and soon closed all organisations, including women's ones.

Russian feminists believed that joining the ICW would promote the women's movement in Russia and that foreign contacts were especially important for provincial organisations far away from modern ideas and trends. They attended ICW congresses with a semi-official status. They popularised the ideas of congresses and the ICW itself through brochures, articles in 'thick journals' 16 and especially feminist ones, and by delivering lectures and reports on the activities of the ICW. Lydia Davydova, one of the delegates to the ICW Congress in London (1899), published an enthusiastic nineteen-page article in the popular literary magazine Mir Bozbii describing the activities of 'our sisters in England and America' and citing them as an example to readers. The article was illustrated with portraits of the leaders of the movement - Lady Aberdeen, Susan B. Anthony and others - who were described in flattering tones (Davydova, 1899).

The idea of 'worldwide sisterhood' was welcomed by Russian feminists. They understood it as a manifestation of female solidarity. They often used the term 'sisterhood' and the title 'sisters' in their speeches and articles in different variations: 'Western sisters', 'Slavic sisters', 'younger sisters', and 'fallen sisters'. Of course, the term 'sisterhood' must be understood from a historical perspective. At that time, it meant overcoming national, confessional, class and political differences. For the Russian ravnopravki, the concept of 'worldwide sisterhood' meant a community (social group) of educated, mainly middle-class women engaged in a profession, from various countries, disregarding national and religious differences. In the Russian women's movement there were a lot of women of different nationalities and ethnic communities such as Polish, German, Jewish, Georgian, and others. They positioned themselves as Russian feminists and as participants of the Russian women's movement. Besides, in the Russian movement, there was a process of challenging class stratification. Representatives of the noble and bourgeois strata formed the backbone of the movement, but the recognition of the universal nature of women's problems forced them to pay attention to women workers and peasant women, whom they called their 'younger sisters', and prostitutes, whom they called 'fallen sisters'. With all the seeming belittling of lower class women by this definition, we need to note that they still used the word 'sisters'. From the very beginning of the women's movement, the 'elder sisters' organised various enlightenment circles for women workers, and then political clubs, and always cited the interests of women of lower social strata in their petitions and demands.

The Russian women's movement immediately responded to the initiative of American women to create a new women's organisation. In 1902, Russian women attended an organisational meeting in Washington and participated in the elaboration of the organisation's declaration. The IWSA defined the right to vote as the main goal of the women's movement. According to the IWSA charter, various organisations from any one country could join. This greatly simplified the application process, as it did not require governmental permission. The IWSA attracted Russians with a clear suffragist agenda, which became relevant to them just at that time. In 1906 the Women's Equality Union joined the IWSA, followed in 1909 by the Women's Progressive Party. The Alliance supported their desire to join, as the accession by such a huge country confirmed the idea of suffragism as a world phenomenon.

At the Congress in Copenhagen (1906), President Carrie Chapman Catt said:

We welcome the Union of Russian Women as a family might welcome daughters who had long been shut away in prison (...) We recognize them as comrades in our common cause. All hail to these heroines of Russia for such they are, and may the dove of liberty soon perch upon their banners! (Report Second and Third Conferences of the International Woman Suffrage Alliance, 1906: 49)

These words reflect the hope which Russian feminists had in 1906, actively promoting the idea of equal rights for women in the first Russian Parliament ${ }^{17}$. The Commission for Women's Equality was created in the First State Duma (1906) under the pressure of feminist organisations (first of all, by the WERU). The WERU, together with the Parliamentary Commission, conducted an expert evaluation of sixteen volumes of the Civil code and developed a bill that provided for equal rights for women and men, and equal rights to vote ${ }^{18}$. Catt's words suggest that she was familiar with the quest for women's suffrage in Russia.

15 These letters are unknown in Russian historiography.

16 'Thick journals' ('tolstye zhurnaly' as they are called in Russian) are monthly magazines which publish news, fictional stories, poetry, literary criticism, and journalistic articles.

${ }_{17}$ The Russian Parliament was named the State Duma.

${ }^{18}$ The bill provided for: the right to vote for women at all levels; the right to hold any position in the state and public service; the right to be elected; the right to have access to all types of education in the co-educational system; the right to equal inheritance; the right to separate property of spouses; and the right to separate residence for spouses. Olga Klirikova, a WERU member, paid for the lawyers' work. The bill was prepared within the shortest time, but the State Duma did not have the 
According to Mirovich, the Russian delegation felt solidarity and support at this congress: they were given twice as much time for reports, and the German delegate, Ms Heyman, called on all participants of the Congress to prevent the granting of loans to the Russian government in their respective countries, as these loans were destined to suppressing revolution and coping with the current crisis. Mirovich summarised the Congress with these words:

The common goal brought together the scattered advocates of equality, gave them mutual moral support. The force is in unity (...) 'Failure is impossible' (Mirovich, 1907b: 48).

The 1909 IWSA London Congress was attended by two Russian women's organisations. The WPP officially entered the IWSA. The Russian government's nightmare came about: the Russian ravnopravki joined an international organisation. ${ }^{19}$ At this Congress, the Russian participants actively supported the militants, introducing an amendment to the Congress resolution, to express sympathy for those 'who in the struggle for equality were imprisoned and thus contributed to the success of the women's movement' (Mirovich, 1909b: 129). They participated in the grand procession of suffragists in London on 27 April, the birthday of Mary Wollstonecraft. At the same time, the Russian delegates considered Carrie Chapman Catt's words as evidence of as support for their achievements: "Women of Russia should look forward with optimism because the day of their liberation is close" (Mirovich, 1909b: 129).

The failure to obtain universal suffrage on the wave of revolutionary protest in 1905 set new tasks for the Russian suffragists. It was necessary to comprehend the reasons for the defeat, especially since the women of the Grand Duchy of Finland, then part of the Russian Empire, gained these rights in 1906 and as many as 19 women deputies were elected to the Finnish Diet. Dreams came true before their eyes at their nearest neighbours, but not at home.

It was necessary to outline a new tactic for promoting the idea of equal political and civil rights for women in various strata of Russian society, in different parties and in social organisations. It was necessary too, to mobilise women from all social groups and classes, to find allies, to develop arguments against opponents, and to lure sympathisers over to their side. They needed a well-developed ideology, popular propaganda literature, and their own publications that spread information about the universal suffrage movement, women's rights and women's problems...There was a lot to do.

There were not so many suffragist organisations. All of them worked with great effort and enthusiasm during these revolutionary years, as they realised that a lot could be achieved in the period of revolutionary change. As Mirovich recalled:

This moment seemed to be particularly favorable for reform: the old order was falling and collapsing. It was substituted with new ideas - universal suffrage and equality before the law (Mirovich, 1908: 4-5).

In 1907, with the decline of the revolution, the WERU was dissolved. It was unable to withstand the intra-party disputes among its members. The League for Women's Equality became its successor (1907-1917), led by Poliksena Shishkina-Yavein, ${ }^{20}$ a doctor, an energetic and pragmatic person (Iukina, 2006).

The years from 1905 to 1914 were the time of the closest and most active contacts of Russian suffragists with international women's suffragist organisations. At the same time, these opportunities were available primarily to members of the WPP, WERU, RWMPS, and LWER, who collaborated with foreign organisations. The metropolitan feminists' goal was to promote not only the idea of suffragism but also the experience of the women's struggle for the right to vote in different countries. They organised lecture tours to promote the idea of suffragism and were engaged in the political education of 'younger sisters'. ${ }^{21}$ The WERU instructed its provincial offices to promote the political rights of women among peasant women and female workers (Ravnopravie zhenshchin, 1906: 13).

Another area of outreach activity was publishing. Publications were aimed at educated women and members of the movement. Publications about international congresses with detailed narrations of reports, analysis of the suffragist organisations' actions around the world and calls to join in the common work for peace, justice, humanism, and morality became constant topics in Russian feminist magazines.

chance to consider it, because the Emperor dissolved the Parliament ahead of schedule. The hope remained that the next convocation of the State Duma would pass the law.

${ }^{19}$ The Russian government's policy was always aimed at curbing the political activity of its subjects and preventing their international contacts. The main problem was, of course, the socialist movements, but the last thing the government wanted was another strong movement with international connections.

${ }^{20}$ Poliksena Shishkina-Yavein (1875-1947) was a physician and the leader of the League for Women's Equal Rights.

${ }^{21}$ For example, in 1905 lectures were delivered in various Russian provincial cities by Mirovich on 'The Women's Movement in England', by A. Kalmanovich on 'The Women's Movement Abroad', and by L. Lenskaya on 'Middle Class Women'. 
The third international women's organisation that officially declared women's suffrage as a goal was the International Socialist Women's Secretariat (IWSS). At the 2nd IWSS conference in Copenhagen in August 1910 , a lively debate broke out on the issue of cooperation with 'bourgeois' feminists on women's suffrage. The latter had been working in this direction for a long time, while the women of the socialist parties had only just turned to this issue. The prevailing opinion was that the proletarian women's movement should be included in the workingclass struggle for universal suffrage. In reality there could be no other solution, as the IWSS was created as a structure of the Second International and, unlike the ICW and IWSA, it was not independent in its decision-making - delegates from national women's socialist organisations were subjected to party discipline and pushed the party line on the issue of women's equality. I agree with Gafizova, who believes that the true goal of the IWSS was to unite proletarian women on the basis of class solidarity, to spread Marxist ideas among female workers, and to counteract the influence of international feminism and suffragism (Gafizova, 2017: 78).

Alexandra Kollontai represented Russia on the IWSS. There was no women's proletarian movement in Russia until 1917, and Kollontai was selected as a participant at the IWSS conferences not by women's proletarian organisations, but by the Russian Social Democratic Labor Party (RSDLP) (Gafizova, 2006). In reality, in the IWSS she was like a general without an army, supported only by female party members who, like her, were in emigration at that time and lived in Geneva, Berlin, Paris and other European cities. Feminist organisations, the so-called 'elder sisters', were working with the 'younger sisters' in Russia at this time. They were the ones who promoted the idea of voting rights for women of all classes as the basis of equality, and thus they gained trust and support of female workers. Women workers took an active part in the events organised by Russian suffragists requesting women's electoral rights. The February Revolution of 1917 began with protests by female workers, but Kollontai had nothing to do with their political socialisation. From 1908 to 1917, she spent time in emigration and returned to Russia only in the spring of 1917, after the February Revolution. Although a member of the IWSS, she was not a suffragist. Rather, she was a soldier of the party and fought against its enemies. She looked on feminists as enemies ever since the First Russian Revolution of 1905, when a broad propaganda campaign among female workers was begun by the suffragists. To belittle the influence of Russian feminists, she sought to discredit them in the eyes of the workers, labelling them 'bourgeois' feminists, although she herself was in reality a representative of their stratum ${ }^{22}$ and of course did not consider herself 'bourgeois'. Also, in her speeches and articles, Kollontai argued that economic rights were more important for female workers than political ones, and convinced them that only women of the well-to-do classes needed electoral rights. I think she understood the importance of voting rights for women as a whole. She saw her task as reducing feminists' influence, splitting the Russian women's movement along class and party lines, and using women to expand the working-class movement. Kollontai's undermining of suffragists caused a corresponding rebuff against her on the part of the latter, and we can read critical analyses and ironic comments in regard to her books and articles throughout the pages of feminist magazines (Shchepkina, 1907).

\section{FEMINIST MAGAZINES}

There were many commercial women's magazines in Russia but the so-called 'ideological' issues which aim to study women's problems in the spheres of education, employment and family appeared in the 1880-90s. They were declared journals 'published by women, for women', in other words initiated, edited and written by women, about women's problems from their 'insider' position, and were addressed to those who cared about possible solutions of those issues. These magazines formed a new concept of woman, creating a language to describe the deep, essential women's problems by constructing a new discourse, which was opposed by counter-discourses - official, liberal and radical discourses in their attitude towards women and their problems.

The next step in the development of women's periodicals was the emergence of publications directly serving the women's movement. They became an important structural element of the suffrage movement. These feminist publications included Pervyi zhenskii kalendar' ('The first women's calendar', 1899-1915, SPb), Zhenskii vestnik (Women's herald, 1904-1017, SPb), Soiuz zhenshchin ('Women's union', 1907-1909, SPb), Zhenskaya mysl' ('Women's thought', 1909-1910, Kiev), and the newspaper Zhenskaya mysl' ('Women's thought', 1909, SPb). When the topic of women's civil rights became acute, all women's magazines at that time had columns devoted to the women's movement at home and abroad. The main mouthpieces of suffragist thought were the monthly magazines $Z$ henskii vestnik and Soiuz zhenshchin.

22 Alexandra Mikhailovna Kollontai (1872-1952) was a noblewoman, the daughter of Lieutenant-General M. A. Domontovich. 


\section{ZHENSKII VESTNIK('WOMEN'S HERALD') 1904-1917}

Годъ IV. 1908 г. №. 9

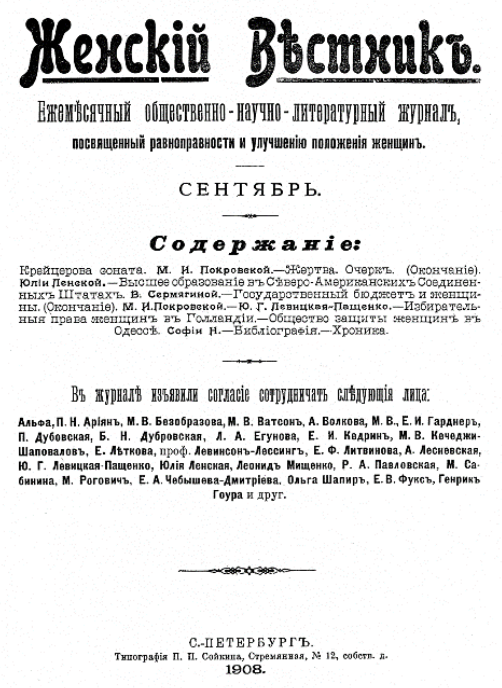

Figure 2. Issue of Zhenskii vestnik ('Women’s herald'). Photograph by I. Iukina.

Zhenskii vestnike ('Women's herald') described itself as a 'monthly social scientific and literary journal on equality and advancement of women'. The editor and publisher was Maria Pokrovskaya23, a doctor and the founder and leader of the Women's Progressive Party (Ruthchild, 2001a). The purpose of the magazine was stated as a discussion of the 'woman question' campaigning for the full equality of women and men, the fight against male domination and the liberation from slavery under men. Pokrovskaya believed that women should have a pulpit:

As long as there is no newspaper or magazine in the hands of women, which they can manage independently and separately from men, they cannot say everything they would like to say about themselves and especially about men (X., 1904: 16).

The magazine did not just describe the facts of injustice against women; it interpreted them through a framework focusing on discrimination and thus constructed a critical feminist discourse. The style of the magazine was acutely critical. Pokrovskaya herself was a fierce polemicist and criticised everyone in the pages of the magazine: ministers, State Duma deputies, and parties. She criticised the government's budget, its foreign and domestic policies.

Along with such familiar topics as women's rights, women's education, women's employment, combating prostitution and eroticism, and news of women's organisations, new topics raised by them appeared in the pages of the magazine. The magazine argued the need to prosecute the male clientele of prostitution, the need to reform women's dress, and the problem of 'women's silence' - the inability and fear of women to speak in public, the right of women as taxpayers to control the spending of state budget funds and so on. The magazine described the reality in a new way and highlighted other aspects of inequality.

The magazine's international section promoted the idea of similarity among women's problems by publishing articles on difficulties in women's education and employment in other countries. It included a review of the activities of women's organisations abroad, the changes in law towards women in various countries, reprints of Jus suffragii and La femme, pieces by delegates of women's congresses, resolutions at congresses, and so on. That information was of great importance for Russian women as it formed the view of women as a specific social group with similar worries all over the world, and formed a collective women's identity irrespective of nationality.

The most important topic was the justification of the possibility of cross-class, cross-party and transnational association of women in the fight for their rights. The theme for Russian society with its huge social polarisation was acute. Zhenskii vestnik pursued the idea of the principled universality of female inequality beyond class, social and national divides and the need for the development of sisterhood to solve women's common problems. The magazine also published rather weak stories from an artistic point of view, describing the psychological problems of women. It was a naive form of feminist propaganda: women were offered samples of a new women's identity,

${ }^{23}$ Maria Pokrovskaya (1852-1922) was a physician, publicist, publisher and founder and leader of the Women's Progressive Party and the Club of Women's Progressive Party.

$10 / 16$

C 2020 by Author/s 
new models of behaviour, and new forms of social participation. Examples of successful women around the world who changed their own destiny - scientists, writers, members of parliament who had achieved public recognition - were described.

Zhenskii vestnik, promoted the idea of creating a nationwide women's organisation - the Russian Council of Women - with the purpose of joining the international women's movement. Although information was published about the situation of women and their struggle in all countries from the United States to China, stories full of admiration on the struggle of English suffragists occupied a central place. Pokrovskaya herself was their ardent supporter.

Zhenskii vestnik, called for women's solidarity and participating in public actions:

Women-mothers! Think if not of yourselves, of your daughters! Teach them to fight for their freedom (...) for their rights, and this will give them happiness and satisfaction in their life! (Tol'ko 'zhenshchina', 1916: 162).

\section{SOIUZ ZHENSHCHIN ('UNION OF WOMEN') 1907-1909}

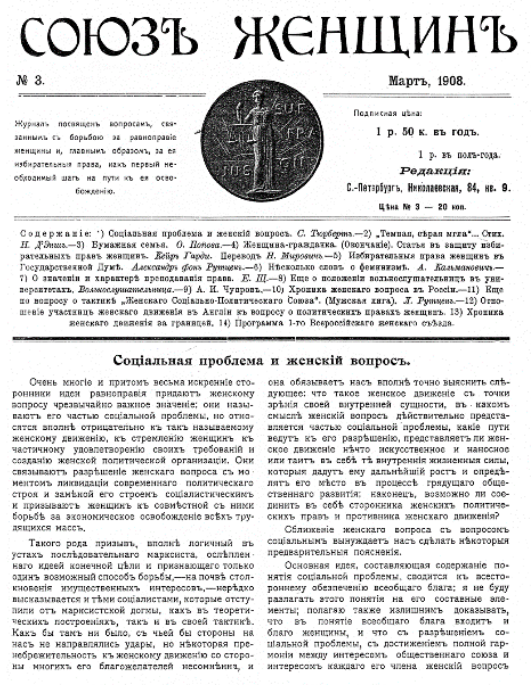

Figure 3. Issue of Soiuz zhenshchin ('Union of women'). Photograph by I. Iukina.

Soinz, zhenshchin ('Union of women') described itself as 'a magazine focusing on issues related to the struggle for women's equality and mainly for their voting rights as the first necessary step towards freedom'. The editorpublisher of this magazine was Maria Chekhova ${ }^{24}$, who was a teacher, and the executive secretary of the Women's Equal Rights Union (Ruthchild, 2006b). The journal was founded by decision of the third congress of the WERU and appears to have been part of the IWSA project. The logo of Jus sufragii on the cover of Soiuz zhenshchin tells us directly about it. The WERU archive contains Catt's address to the national organisations urging them to promote the idea of suffragism, and to this end to appoint a responsible person who had studied the local and the international press on the suffrage movement and had prepared material for publication (GARF, f. 516, Op. 1, Ed. khr. 11. L. 89) In Soiuz, zhenshchin this work was performed by Zinaida Zhuravskaya ${ }^{25}$.

The aim of the magazine was to enlighten society and raise its consciousness 'for the correct solution to the woman question in the future': "We have prepared this issue to promote our public consciousness" (Peterburg, Iyun', 1907: 2). One more goal was to create solidarity for women. The magazine appealed to women, for whom:

we set the task together with the whole Western world, firmly believing that, without realizing this idea in life, neither the democratization of society nor radical social reforms can be implemented, to fight for the rights (...) Women are aware of this and form themselves into societies and unions and fight for the political rights of women both in the West and in Russia. This organized fight (...) will take up not the last place in our magazine (Peterburg, Iyun', 1907: 2).

\footnotetext{
${ }^{24}$ Maria Chekhova (1866-1937) was a teacher and leader of the Women's Equal Rights Union.

${ }^{25}$ Zinaida Zhuravskaya (1867-1937) was a well-known translator of all major European languages, pianist, writer and an active participant in the feminist movement.
}

(C) 2020 by Author/s 
The first editorial message to readers stated that this is a time when 'the political and civil equality of women is moving from the realm of good wishes and utopian dreams to real ground' (Peterburg, Iyun', 1907: 1).

Recall that, despite the fact that the first Russian Parliament, the first State Duma session, was dissolved in 1906 without having adopted the law on political rights of women, a bill on granting women electoral rights was drafted. According to observers, the chance that it would be adopted was very high, because in the first State Duma there were many supporters of women's equality. Women of the Grand Duchy of Finland, which at that time was part of the Russian Empire, received electoral rights in that same year of 1906. Therefore, the enthusiasm of the publishers was reasonable and the goal was set accordingly - to enlighten women and men in the 'woman question', to develop their solidarity, to influence public opinion. This required people 'from all sides to study the woman question', to subject it to scientific development, including the foreign experience. At the same time the ravnopravki perfectly understood the cultural and political particularities of Russia and therefore promised:

To bring all this scientific material in close relation to the real life of Russia, taking into account all the features of the historical and cultural development of the country and all the diverse local conditions of our homeland (Peterburg, Iyun', 1907: 1).

The magazine reported extensively on the international suffragist movement: it represented women's organisations and their tactics, and printed material on the IWC and IWSA and women's congresses, information on the status of women's suffrage in other countries, the appeal of Catt calling on Russian women to unite, and asserting the universality of women's problems all the world as well as proposing solutions. Needless to say, the experience of English suffragists was examined from every angle here. Mirovich (Zinaida Ivanova), Anna Kalmanovich, Zinaida Zhuravskaya, Ludmila von Ruttsen ${ }^{26}$, Maria Vakhtina ${ }^{27}$, Elizaveta Goncharova, Maria Blandova ${ }^{28}$ and so on, wrote much on this (Ruthchild, 2001b).The magazine considered suffragism a factor of world progress and promoted its main ideas. The struggle for the right to vote was considered the moral duty of women: The only popular representation in which a female legislator will stand next to a male one, will lead to freedom from social slavery (Peterburg, Iyun', 1907: 2).

On the pages of Soiuz zhenschin were presented specifically Russian national features in the women's movement first, the hope men, 'in the tradition of our Russian reality,' will remain comrades on the path of systematic legislative work in the struggle for women's rights (Peterburg, Iyun', 1907: 2). Secondly, the claim for all women should enjoy the same voting rights. Intelligent women were responsible for 'younger sisters' - women-peasants, women-workers and prostitutes. Protecting their interests was described as the duty of middle-class educated women. So, the idea of limited suffrage for women was not accepted by Russian suffragists. The magazine promoted women's suffrage without distinction as to religion, nationality, and class. However, with the government's reactionary policy intensifying, the Russian suffragists had to adopt the tactics of English suffragists and agree to a limited women's suffrage. But they immediately restored the requirement of universal suffrage to their banners as soon as the situation in the country changed and dissatisfaction with government policy and World War I began to grow.

The main tactical line of the magazine was respect for the political views and party affiliation of the members of the women's movement and their unification on the platform of worldwide sisterhood and universal suffrage. Common women's interests, unified women's movement irrespective of belonging to any classes or parties - the principle position of the magazine. Therefore, anybody received a rostrum here: women-socialists, women-liberals and women-non-partisan on its pages.

At the end of 1909 the magazine ceased to exist. Publication by people of different political views and with different party affiliations proved incredibly difficult. The party interests of the editorial board members undermined the universality of the idea of sisterhood. However, hope for the revival of the magazine remained. In the last issue, Maria Chekhova wrote: "We do not say goodbye, we say see you later".

Peryyi zhenskii kalendar' ('The first women's calendar'), Zhenskaya mysl' ('Women's thought') and practically all women's magazines of a commercial nature before World War I had regular sections on news of the international women's movement. Even the fashion magazine Novyi russkii bazar ('The new Russian bazaar') had the section Chronicle of Women's Affairs. The discursive field of Russian suffragism as part of the international scene was formed by joint effort.

\footnotetext{
${ }^{26}$ Ludmila von Ruttsen was a feminist activist and one of the founders of Women's Equal Rights Union.

${ }^{27}$ Maria Vakhtina was a publicist and member of the Women's Political Party.

${ }_{28}^{2}$ Maria Blandova was a writer and feminist activist.
} 


\section{JUS SUFFRAGII (1906-1924)}

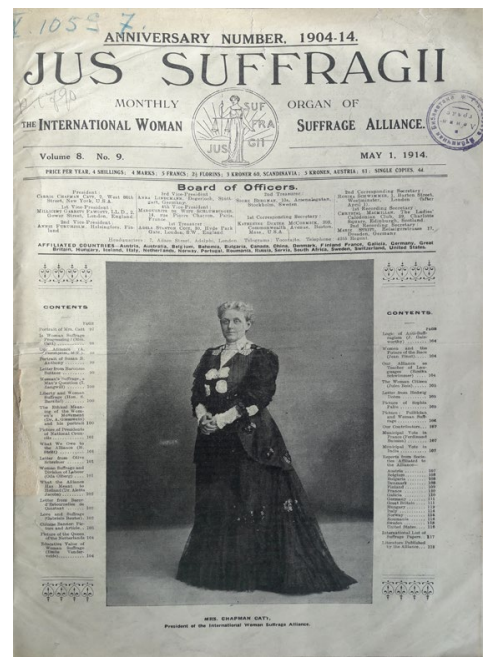

Figure 4. Issue of Jus suffragii. Photograph by I. Iukina.

Jus suffragi $i^{29}$ was especially important to Russian suffragists. It provided them with an international platform, allowing them to talk about the women's movement in Russia: their hopes, activities, victories and defeats. Russian feminist magazines, could not be read by the foreign suffragists; hardly any of them knew Russian. English in turn was an obstacle for many Russians. Educated Russian women of that time necessarily knew two foreign languages. French was taught from the childhood, it was the language of communication among the nobility. Besides, they also studied German in the gymnasia, a language popular in intellectual circles. English was not in vogue; it was studied only by the highest aristocracy close to the Court only, as it was the 'home' language of the Emperor Nicholas II and Empress Alexandra Feodorovna. As we know from an interview given by Anna Kalmanovic to Jus suffragii during her visit to London, she was a regular subscriber to the magazine and specifically learned English in order to read it (A Banner-Bearer in Russia, 1912: 160-161).

Several Russians joined the journal Jus suffragii as correspondents. Mirovich, Chekhova, Kalmanovich, Goncharova, Shishkina-Yavein, Zhuravskaya and others mediated the discourse with Western feminists: they not only published articles about the women's movement and the situation of women and gender relations in Russia for foreign readers, but also kept the Russian public informed about the international women's movement. N. Mirovich and Anna Kalmanovich wrote especially on English suffragism. They both supported the militants. Mirovich lived in England for a long time, had strong ties with English suffragists, was a member of two English women's organisations (unfortunately we do not know which ones), participated in their activities, and spoke at suffragist meetings at Hyde Park Corner (Bezobrazova, 1913: 216). It can be said that she was a professional researcher of the international women's movement looking for the universal and private in the women's movements of various countries. She investigated the reasons behind Finnish women's victory, raising questions in her brochure: what was position they occupied in society and in the family, how did they struggle for equality, what elements of society participated in this struggle, and what was the role played by political events in Finland? (Mirovich, 1907a: 9). Mirovich saw in the victory of Finnish suffragists an example of cross-class solidarity of the entire Finnish people, and she saw the spirit of freedom and independence inherent in the Finns, the catalyst for victory, remarking that the requests of women were included in the agenda of their all-national liberation struggle. She concluded that Russians should raise the consciousness of all people and welcomed the success of the Finnish women:

We, women of Russia lagging behind Finnish suffragists in political life, appeal to them with warm greetings and our most sincere wishes for success in further activities. We rejoice in the victory of our sisters in Finland as our own. Their example inspires us and breathes cheerfulness and energy into us, and their experience serves as a guiding star for us (Mirovich, 1907a: 20).

Based on her observations, her conclusions stated that women from 'the countries with Roman and Slavonic populations are more inert and passive than German and Anglo-Saxon ones' (Mirovich, 1909b: 129).

In turn, in an interview with Jus suffrage, Anna Kalmanovich demonstrated good knowledge of the activities of English suffragists and expressed enthusiastic support for them. Apparently, enthusiasm for each other seems to be a specific style of writing in the feminist press of the time. An unknown correspondent of Jus suffragii also

${ }^{29}$ The IWSA established Jus Suffragii as the official journal of the organisation. This title means in Latin 'the right of suffrage'. 
admiringly described 'Madame' Kalmanovich. Anna Kalmanovich was one of the few Russian radical feminists, an active member of the WERU and its successor the League for Women's Equal Rights. She supported the tactics of the English militants, wrote a brochure Suffragist and Suffragettes (1911), and translated the pamphlet of Christabel Pankhurst The Great Scourge and How to End It (1914) into Russian.

World War I split the international women's movement. First, the question of the fundamental possibility of cooperation with organisations of the belligerent powers arose. Russian feminists saw the support for their government and work towards victory as their civic responsibility. For them, that was a symbolic entry into citizenship. Moreover, contact with the movements of the Allied countries continued. Jus suffragii printed information on the activities of Russian organisations; Zhenskii vestnik continued to maintain an international section and published articles on international suffrage. Their texts promoted rapprochement of positions, and the development of one common language.

Studying the experience of international suffrage, of course, helped the Russian ravnopravki to comprehend their national characteristics and build their own path to achieving the goal. They borrowed many forms of work: women's congresses, rallies, processions and demonstrations. They accepted and tested the main principle of the struggle for suffrage - not to believe in any promises and go through their demands to the end (Zacuta, 1917: 126). However, they did not accept and did not use violent actions. Many Russian feminists admired the courage of the militants. N. Mirovich, for example, believed that the militants were 'the young, perky vanguard of the movement' (Mirovich, 1909b: 126), while the representatives of the National Union 'were not able to rule the crowd: they were too well-bred for this, too fastidious', and considered that "the appearance of the suffragettes on stage gave the whole movement unprecedented energy and strength" (Mirovich, 1909a: 812).

Other activists considered their methods to be aggressive and thoughtless. But even those who supported the militants and justified them never offered to use their methods in Russia, believing that there was too much political violence in the country both from the radical elements and from the government. Another difference, as already mentioned, was their fundamental refusal to submit to only limited suffrage, and the struggle for universal women's suffrage.

\section{CONCLUSION}

Russian educated suffragists women clearly saw the gap in economic, social and political development between Europe, the US and Russia due to the process of 'catching up' or 'late modernisation'. Recognising the mission of the pioneers of the 'Western sisters' and taking the position of followers, they nevertheless adhered to the idea of the specificity of suffragism in different countries and the importance of any experience. Therefore, they developed solidarity (sisterhood), used other movements' experience, and shared their own ones. The universal tool for this was the printed word. In addition to articles and brochures, they printed and distributed leaflets for the various social strata, for men and women, on the need for political equality. They argued that women are better suited for public work because of their specific 'feminine qualities' especially in the areas of health, sanitation and hygiene, education, and urban governance, and illustrated this with examples from other countries. Thus, they formed and promoted feminist discourse in Russian society and a new women's civic identity, and they created the image of the women-citizen.

Ravnopravki were good apprentices. In the short time that Russian suffragism existed for essentially twelve years, public opinion adopted the idea of women's citizenship and the expression 'women-citizen' became used at least among the urban population. This work turned into a victory in the spring of 1917, when the League for Women's Equal Rights (the successor of WERU) called out a 40,000 column of women from various social classes which moved on the Tauride Palace, seat of the Provisional government ${ }^{30}$.

In response to the pathos of speeches of the representatives of the Provisional government and its assurances of sympathy for women, the leader of the LWER, Poliksena Shishkina-Yavein, pointed to the fact that the new electoral law Bill again ignored women:

We believe in your inalienable right to be equal in the new free Russia (...) And meanwhile (...) the convocation of the Constituent Assembly was proposed on the basis of universal, direct, equal and secret ballot - but you forgot to mention equal rights for men and women (...) and recalling our overseas sisters [italics - I. Iukina], we have come to tell you that the Russian woman demands human rights for herself too (...) We are not leaving here until we get an answer. (Zacuta, 1917: 6)

${ }^{30}$ Women's rights demonstration was on March 19 $9^{\text {th }}, 1917$.

$14 / 16$

(C) 2020 by Author/s 
The Provisional government was thus obliged to give a positive response. For four months women applied rigid and consistent pressure to the new government, which, step by step, yielded. ${ }^{31}$ On July $20^{\text {th }}, 1917$ the Provisional government enacted a Bill 'On the official position of elections to the Constituent Assembly'. According to it, full voting rights were granted to 'Russian citizens of both sexes' who, by Election Day, would have attained twenty years of age. It entered into force on 11 September 1917. It was a victory by and for women.

It is not enough to explain this victory only by the then political crisis caused by war and revolution. The hard work of the Russian ravnopravki, based on the experience of and solidarity with movements in other countries, led them to their goal. Soviet propaganda claimed that women's right to vote was an achievement of socialism. The Russian suffragists knew that this was a lie. But what could they do? The Soviet people were denied access to the historical truth, namely that women's suffrage was won by Russian women themselves in a hard struggle, primarily of middle-class women with the support of women from other social strata, mainly urban. In 1921 Anna Shabanova, ${ }^{32}$ former leader of the RWMPS, wrote in a letter to Mrs. Backer sent through private channels, that voting rights for women in Russia were achieved by intelligent women, the so-called 'female bourgeoisie' (Novikova, 2006a; Ruthchild, 2010: 252).

\section{REFERENCES}

A Banner-Bearer in Russia: Madame Anna Kalmanovitsch. (1912). Jus suffragii, January 27, Saturday, $160-161$.

Bezobrazova, M. (1913). Pobornica nashego ravnopraviay (na smert' Mirovich). Zhenskii vestnik, 9, 216.

Cohen, L. R. (2012). Early endeavors to establish a (Soviet) Russian WILPF. Section, 1915-1925. A little known episode in feminist transnational peace history. Deportate, elusi, profughe. Rivista telematica di studi sulla memoria femminili, 18-19, 178-198. Available at: https://www.unive.it/pag/31498/ [date accessed 13.02.2020]

Davydova, L. (1899). Na zhenskom mezhdunarodnom kongresse: pis’mo iz Londona. Mir Boz̧bii, 8, 42-60.

Edmondson, L. H. (1984). Feminism in Russia, 1900-1917. Stanford, California: Stanford University Press.

Gafizova, N. (2003). Vzaimodeistvie rossiiskogo zenskogo dvizheniya i mezhdunarodnyrh zenskikh organizacii v konce XIX - nachale XX veka, in O. A. Khasbulatova and N. B. Gafizova. Zhenskoe dvizhenie v Rossii (vtoraya polovina XIX - nachalo XX veka) (pp. 112-155). Ivanovo: Izdatelstvo 'Ivanovo'.

Gafizova, N. (2006). Alexandra Kollontai, in F. De Haan, K. Daskalova, and A. Loutfi (eds.), A Biographical Dictionary of Women's Movements and Feminisms: Central, Eastern and South Eastern Europe, 19th and 20th Centuries (pp. 253-257). Budapest: Central European University Press.

Gafizova, N. (2017). Feminism, class i partiay v strategiyakh vzaimodeistviya mezhdunarodnogo i rossiiskogo zhenskogo dvizheniya $\mathrm{v}$ nachale XX v. Zhenshchina v rossiskom obshchestve, 2, 74-83.

Gosudarstvennyi Arkhiv Rossiskoi Federacii (GARF). Fond. 516. Opis. 1. Ed. khr. 11. List. 89

Kal'manovich, A. A. (1905). Otchet o Zhenskom Mezhdunarodnom Kongresse 1904 g. Saratov: Tipo-litografiya G.Kh. Shel'gorn.

Maslova, L. I. (1907). Woman about Women. St. Petersburg: Tip. Al'tshulera.

Mill, J. St. (1907). Iz̧biratel'nye prava z̧henshchin. Perevod N. Mirovich. Moscow: Tip. I.D. Sytina.

Mirovich, N. (1901). Dva kongressa zhenskoi frondy (iz vospominanii 1899 i 1900 gg.), in Sbornik na pomoshch' uchashchimsya zhenshchinam (pp. 233-255). Moscow: Tipo-litographia T-va I.N. Kushnerev i Ko.

Mirovich, N. (1907a). Pobeda ₹̧henskogo dviðheniay v Finlayndii. Moscow: Tipo-litographia T-va I.N. Kushnerev i Ko.

Mirovich, N. (1907b). Zhenskoe dvizhenie v Evrope i Amerike (Tretii Kongress Mezhdynarodnogo souza izbiratel'nyckh prav zhenshchin'v Kopengagene). Moscow: Tip. I.D. Sytina.

Mirovich, N. (1908). Iz istorii zhenskogo dvizheniay v Rossii. Doklad, chit. 9 avgusta 1908 g. v Kopengagene na kongresse 'Mezhdunar. sousa izbirat. prav zhenshin'. Moscow: Tip. I.D. Sytina.

Mirovich, N. (1909a). Novyi fazis zhenskogo dvizheniay v Anglii. Vestnik Evropy, 8, 810-819.

Mirovich, N. (1909b). Zhenskii parlament v Londone (26 aprelya - 1 maya 1909 g.) Russkaya mysl', 7 (VII), $124-$ 137.

Muravyeva, M. (2006a). Anna Filosofova, in F. De Haan, K. Daskalovaand A. Loutfi (eds.), A Biographical Dictionary of Women's Movements and Feminisms: Central, Eastern and South Eastern Europe, 19th and 20th Centuries (pp. 135-139). Budapest: Central European University Press.

\footnotetext{
${ }^{31}$ Meeting of the delegation of suffragettes with the Head of the Provisional Government, Prince Lvov, and giving him a petition from women's organisations, demanding for the right to vote; a newspaper campaign with the publication of letters from women's organisations from all over the country; representatives of women's organisations entered a Special Committee to develop a bill on elections to the Constituent Assembly; etc.

32 Anna Shabanova (1848-1932) was a physician and founder of the Russian Women's Mutual Philanthropic Society.
}

(C) 2020 by Author/s 
Muravyeva, M. (2006b). Nadezhda Stasova, in F. De Haan, K. A. Loutfi (eds.), A Biographical Dictionary of Women's Movements and Feminisms: Central, Eastern and South Eastern Europe, 19th and 20th Centuries (pp. 526-229). Budapest: Central European University Press.

Novikova, N. (2006a). Anna Shabanova, in F. De Haan, K. Daskalova, and A. Loutfi (eds.), A Biographical Dictionary of Women's Movements and Feminisms: Central, Eastern and South Eastern Europe, 19th and 20th Centuries (pp. 498-502). Budapest: Central European University Press.

Novikova, N. (2006b) Maria Trubnikova, in F. De Haan, K. Daskalova, and A. Loutfi, A. (eds.), A Biographical Dictionary of Women's Movements and Feminisms: Central, Eastern and South Eastern Europe, 19th and 20th Centuries (pp. 584-587). Budapest: Central European University Press.

Peterburg, Iyun'., 1907 g. (1907). Soiuz zhenshchin, 1, 1-2.

Ravnopravie zhenshchin. Otchety i protokoly. (1906). St. Petersburg, 13.

Report Second and Third Conferences of the International Woman Suffrage Alliance. (1906). Copenhagen.

Ruthchild, R. (2001a). Pokrovskaia, Maria Ivanovna, In N. C. Noonan. and C. Nechemias (eds.), Encyclopedia of the Russian Women's Movements (pp. 55-57). Westport, Connecticut - London: Greenwood Press.

Ruthchild, R. (2001b). Ruttsen (or Von-Ruttsen), Ludmila Ivanovna, in N. C. Noonan, and C. Nechemias (eds.), Encyclopedia of the Russian Women's Movements (pp. 64-65). Westport, Connecticut - London: Greenwood Press.

Ruthchild, R. (2006a). Anna Kal'manovich, in F. De Haan, K. Daskalova, and A. Loutfi (eds.), A Biographical Dictionary of Women's Movements and Feminisms: Central, Eastern and South Eastern Europe, 19th and 20th Centuries (pp. 207-209). Budapest: Central European University Press.

Ruthchild, R. (2006b). Maria Chekhova, in F. De Haan, K. Daskalova, and A. Loutfi (eds.), A Biographical Dictionary of Women's Movements and Feminisms: Central, Eastern and South Eastern Europe, 19th and 20th Centuries (pp. 95-98). Budapest: Central European University Press.

Ruthchild, R. (2006c). Zinaida Mirovich, in F. De Haan, K. Daskalova, and A. Loutfi (eds.), A Biographical Dictionary of Women's Movements and Feminisms: Central, Eastern and South Eastern Europe, 19th and 20th Centuries (pp. 544-547). Budapest: Central European University Press.

Ruthchild, R. G. (2010). Equality \& Revolution: Women's Rights in the Russian Empire 1905-1917. Pittsburgh: University of Pittsburgh Press.

Shchepkina, E. (1907). Apologiya "burzuazok" v knige gospozhi Kollontai "Social'nye osnovy zhenskogo voprosa". Soiuz zhenshchin, 4, 11-14.

Shnyrova, O. (2009). Women's victory or the impact of revolution? Peculiarities of women's suffrage in Russia, in I. Sulkunen, S.-L. Nevala-Nurmi, and P. Markkola (eds.), Suffrage, Gender and Citizenship: International Perspectives on Parliamentary Reforms (pp. 146-159). Cambridge: Cambridge Scholars Publishing.

Shnyrova, O. (2016). The woman's question and the national question in the Russian Empire: Interconnections between central and borderland women's suffrage organizations during the First Russian Revolution, 19051907, in C. Midgley, A. Twells, and J. Carlier (eds.), Women in Transnational History. Connecting the local and the global (pp. 98-116). Abingdon, Oxfordshire: Routledge.

Stites, R. (1978, 1991). The Women's Liberation Movement in Russia: Feminism, nibilism, and bolshevism, 1860-1930. Princeton, N. J.: Princeton University Press.

Student V. V. Lush. (1907). Doklad A. A. Kalmanivich. Soiuz Zhenshchin, 5, 19.

Tol'ko "zhenshchina". (1916). Zhenskii vestnik, 12, 162.

Tyrkova, A. V. (1915). Sbornik pamayti Anny Pavlovny Filisofovoi (1837-1912). Vol. 1.

Petrograd: Tov-vo R. Golike and E. A. Vilborg.

X. (1904). Zhenshchiny-zhurnalistki za granicei. Zhenskii vestnik, 1, 14-16.

Iukina, I. (2006). Poliksena Shishkina-Iavein, in F. De Haan, K. Daskalova, and A. Loutfi(eds.), A Biographical Dictionary of Women's Movements and Feminisms: Central, Eastern and South Eastern Europe, 19th and 20th Centuries (pp. 510-513). Budapest: Central European University Press.

Zacuta, O. (1917). Kak v revilucionnoe vremay Rossiiskaya Liga ravnjpraviay zhenshchin dobilas' izbiratel'nykh prav dlay russkikh zhenshchin. Petrograd: Vserossiiskaya Liga Ravnopraviya zhenshin.

Zhenshchiny ne priznayutsya v Rossii naseleniem. (1906), Zhenskii Vestnik, 1, 1.

Citation: Iukina, I. (2020). Russian Suffragists and International Suffragist Organisations: Solidarity, Discipleship, Victory. Feminist Encounters: A Journal of Critical Studies in Culture and Politics, 4(2), 25. https://doi.org/10.20897/femenc/8513

Copyright (C) 2020 by Author/s and Licensed by Lectito BV, Netherlands. This is an open access article distributed under the Creative Commons Attribution License which permits unrestricted use, distribution, and reproduction in any medium, provided the original work is properly cited. 